\title{
HUBUNGAN PROMOSI MENGGUNAKAN INTERNET TERHADAP PERILAKU PEMBELIAN TIDAK TERENCANA (STUDI KASUS PADA MAHASISWA DAN DOSEN UNIVERSITAS MUHAMMADIYAH MATARAM)
}

\author{
Wirawan Jaya Darma', Novia Suhastini² \\ Jurusan Ilmu Pemerintahan Universitas Muhammadiyah Mataram \\ Email: noviasuhastini@ymail.com
}

\begin{abstract}
ABSTRAK
Konsumen Indonesia memiliki sepuluh karakter unik, yaitu berpikir jangka pendek, tidak terencana, suka berkumpul, gagap teknologi, berorientasi pada konteks, suka merek luar negeri, religius, gengsi, kuat di sub kultur, dan kurang peduli lingkungan. Sebagian besar konsumen Indonesia memiliki karakter unplanned ditambah lagi dengan munculnya istilah e-comerce atau $e$ buisnes yang merupakan salah satu perkembangan teknologi untuk mempermudah konsumen untuk berbelanja kapan saja. Dengan demikian penelitian ini akan melihat hubungan promosi melalui internet terhadap perilaku pembelian tidak terencana oleh konsumen. Metode penelitian yang digunakan adalah pendekatan kuantitatif yaitu pendekatan ilmiah terhadap pengambilan keputusan manajerial dan ekonomi, dalam penelitian ini berdasarkan dan data-data diperoleh dari wawancara dan kuisioner. Jenis penelitian menggunakan penelitian ex-post facto, karena didalam penelitian ini tidak dibuat perlakuan atau manipulasi terhadap variabelnya tetapi mengungkap berdasarkan gejala yang telah ada pada diri responden. Hasil penelitian menunjukkan ada hubungan yang positif dan signifikan secara simultan antara periklanan dan promosi penjualan menggunakan internet terhadap perilaku pembelian tidak terencana pada Mahasiswa Dan Dosen Universitas Muhammadiyah Mataram. Hal ini dibuktikan dengan nilai F-hitung $(14,765)$ lebih besar dari F-tabel dengan taraf signifikasi $5 \%$ dan $\mathrm{N}=97(3,09)$.
\end{abstract}

Kata Kunci: Promosi Internet, Perilaku pembelian tidak terencana.

\section{LATAR BELAKANG}

Globalisasi perekonomian merupakan suatu proses kegiatan ekonomi dan perdagangan, dimana negaranegara di seluruh dunia menjadi satu kekuatan pasar yang semakin terintegrasi dengan tanpa rintangan batas teritorial negara. Ketika globalisasi ekonomi terjadi, batas-batas suatu negara akan menjadi kabur dan keterkaitan antara ekonomi nasional dengan perekonomian internasional akan semakin erat. Begitu banyaknya perusahaan-perusahaan baru yang muncul akhir-akhir ini merupakan sebuah fenomena alamiah yang muncul dari adanya globalisasi ini. Hal tersebut tentunya akan membuat peta persaingan di antara perusahaan-perusahaan tersebut semakin ketat. Menurrut Kotlet et al (dalam Isnu 2011) adalah bahwa kenyataannya pasar lebih cepat berkembang daripada pemasar. Karena itu pemasar harus didekonstruksi, didefinisi dan dibentangkan seluas mungkin. Karena pemasar haruslah beradaptasi dengan situasi pasar untuk bisa menyelaraskan situasi tersebut.

Indonesia dengan jumlah penduduk lebih dari 250 juta jiwa dan merupakan Negara ke empat dengan populasi terbesar didunia setelah China, Amerika Serikat dan India. Menjadikan Indonesia sebgai target pasar bagi perusahaan-perusahaan besar baik yang berasal dari luar negeri maupun dari dalam negeri. Salah satu cara yang dilakukan oleh perushaan-perusahaan tersebut untuk mendapatkan pasar potensial adalah dengan cara mengenali karakteristik atau perilaku konsumen yang ada di Indonesia. Dengan cara mengetahui perilaku konsumen yang ada di Indonesia para pelaku usaha dapat dengan mudah mengambil keputusan dalam menyusun starategi apa yang cocok untuk menarik minat konsumen.

Handi Irawan (dalam Revalia, 2014), konsumen Indonesia memiliki sepuluh karakter unik, yaitu berpikir jangka pendek, tidak terencana, suka berkumpul, gagap teknologi, berorientasi pada konteks, suka merek luar negeri, religius, gengsi, kuat di sub kultur, dan kurang peduli lingkungan. Sedangkan menurut Rahmat Susanta (2007) salah satu pemimpin redaksi majalah marketing, sebagian besar konsumen Indonesia memiliki karakter unplanned. Mereka biasanya suka bertindak "last minute".Jika berbelanja, mereka sering menjadi pembeli yang spontan (impulse buyer). Dengan karakteristik tersebut perusahaan diharapkan dapat mengeluarkan strategi pemasaran yang dapat menunjang perusahaannya. 
Pembelian tidak terencana atau biasa disebut juga Impulse buying adalah perilaku orang dimana orang tersebut tidak merencanakan sesuatu dalam berbelanja. Konsumen yang melakukan pembelian tiba-tiba tidak berpikir untuk membeli produk atau merek tertentu. Mereka langsung melakukan pembelian karena ketertarikan pada merek atau produk saat itu juga. Menurut Rook, Fisher (dalam Negara dan Dharmmesta, 2003) mendefinisikan Pembelian tidak terencana sebagai kecenderungan konsumen untuk membeli secara spontan, reflek, tiba-tiba, dan otomatis. Dari definisi tersebut, terlihat bahwa pembelian tidak direncanakan Merupakan sesuatu yang alamiah dan merupakan reaksi yang cepat. Pembelian tidak direncanakan bisa terjadi dimana saja dan kapan saja, termasuk pada saat seorang penjual menawarkan suatu produk kepada calon konsumen. Dimana sebenarnya produk tersebut terkadang tidak terpikirkan dalam benak konsumen sebelumnya. Menurut Utami (2006), produk yang dibeli tanpa rencana sebelumnya disebut produk impulsif. Misalnya seperti majalah, minyak wangi, dan produk kosmetik.

Engel \& Blackwell (dalam Revalia, 2014) mengemukakan bahwa pembelian impulsif (Pembelian tidak terencana) dapat dikategorikan dalam empat kategori, yaitu pembelian impulsif murni, pembelian impulsif karena ingatan, pembelian impulsif secara sugesti, dan pembelian impulsif yang direncanakan. Lebih jauh pembelian yang merencanakan untuk membeli produk tetapi belum memutuskan fitur dan merek yang dibutuhkan dapat juga dikelompokkan sebagai pembeli impulsif. Dalam situasi seperti ini, konsumen akan menggunakan toko ritel dan promosi penjualan sebagai alat mendapatkan informasi, mngembangkan alternatif, membandingkan produk, kemudian melakukan keputusan pembelian yang diinginkan. Selain itu, dapat saja konsumen yang menemukan informasi menggunakan internet (online), tetapi memutuskan pembelian secara lansung (offline), itupun dikategorikan sebagai salah satu bentuk pembelian impulsif. Dengan demikian, karakteristik pembelian produk melalui informasi iklan internet berpotensi untuk masuk kategori pembelian impulsif seperti membeli produk lainnya.

Kemajuan teknologi informasi dan komunikasi saat ini mendorong perilaku pembelian tidak direncanakan semakin sering terjadi. Hal ini timbul karena baik konsumen dan pemasar sangat dengan mudah bertukar informasi mengenai sebuah produk atau barang tertentu. Hal itu disebabkan karena kemajuan teknologi yang ada seperti dalam melakukan praktek pemasaran baik pemasar dan konsumen telah mengguanakan sebuah sistem yang mampu mengintegrasi semua aspek pasar yang ada, sehingga cara yang konvensional lambat laun semakin ditinggalkan.

Salah satu contoh damapak kemajuan teknologi informasi dan komunikasi dibidang bisnis saat ini adalah munculnya istilah $e$-comerce atau $e$ buisnes yaitu penggunaan jaringan komunikasi dan komputer untuk melaksanakan proses bisnis. Yang menjadi permbeda dari e-comerce adalah penggunaan internet dan komputer dengan browser web untuk membeli dan menjual produk. McLeod Pearson (2008 : 59). Sementara itu menurut Shely Chasman (2007 : 83) E-comerce atau kependekan dari electric commerce (perdagangan secara elektrik) merupakan transaksi bisnis yang terjadi dalam jaringan elektronik seperti internet. Siapa yang dapat mengakses komputer, memiliki sambungan ke internet, dan memiliki cara untuk membayar barangbarang atau jasa yang mereka beli, dapat beerpartisipasi dalam $e$-commerce.

Namun saat ini seirng dengan berkembangnya zaman, pengertian e-commerce menjadi semakin luas. Komputer bukanlah salah satu alat yang menjadi syarat untuk melakukan transaksi secara elektronik, saat ini telpon genggam (handphone) juga bisa digunakan dalam melakukan transaksi melalui internet dengan syarat, handphone tersebut haruslah terhubung dengan jaringan internet. Dengan begitu aktivitas jual beli menggunakan internet atau yang lebih dikenal dengan jual beli online atau online shop dapat dilakukan oleh siapa saja, kapan saja dan dimana saja,

Dengana adanya hal tersebut konsumen sekarang dipermudah dengan tidak harus pergi ke toko atau tempat perbelanjaan untuk mendapatkan barang dan jasa yang diinginkannya cukup dengan menggunakan perangkat seperti handpone, komputer atau laptop mereka bisa melakukan berbelanja kapan saja dan dimana saja. Sultan dan MD Nasir (2011) dalam tulisannya menyatakan sejauh ini secara global lebih dari 627 juta orang di dunia telah melakukan belanja menggunakan internet, termasuk pembeli menggunakan internet terbesar dunia, yaitu Jerman dan Inggris.

Perubahan teknologi komunikasi yang sangat cepat dan mengglobal, telah memberikan kesempatan para pemasar yang lebih luas dan efisien. Pertimbangan dunia bisnis saat ini perusahaan menggunakan internet sebagai cara untuk menjangkau pelanggan secara global, telah membawa beberapa dampak transformasional pada beberapa aspek kehidupan termasuk perkembangan dunia bisnis. Kelebihan berbelanja menggunakan internet (online shop) adalah selain pembeli bisa melihat desain produk yang sudah ada konsumen juga bisa memesan desain hingga pembayaran menggunakan internet juga (Ismu,2011). 
Pengenalan produk pada konsumen merupakan cara awal perusahaan untuk memberikan pembelajaran mengenai produk mereka. Cara ini biasa disebut dengan promosi. Kotler dan Keller (2009) menyatakan bahwa promosi adalah berbagai cara untuk menginformasikan, membujuk, dan mengingatkan konsumen secara langsung maupun tidak langsung tentang suatu produk atau brand yang dijual. Dalam mencapai promosi yang baik, perusahaan juga menyampaikan harga yang ditawarkan. Kotler dan Keller (2009) menyatakan didalam promosi terdapat berbagai bentuk promosi atau yang dikenal dengan bauran promosi (promotion mix) diantaranya seperti periklanan, promosi penjualan, direct marketing, public realiation dan personal selling.

Dalam melakukan sebuah promosi, perusahaan haruslah membuat sebuah media promosi yang sekiranya dapat dengan mudah menjangkau dan dapat dengan mudah di pahami oleh setiap orang. Oleh karenanya promosi menggunakan media internet saat ini dirasa begitu efektif dalam menyampaikan sebuah promosi, di internet sendiri bauran promosi yang lebih dominan dan banyak dipakai oleh pemasar adalah periklanan dan promosi penjualan hal itu dikarenakan melalui internet kedua bauran promosi itu lebih maksimal dalam proses penyampainnya kepada calon konsumen.

\section{KERANGKA TEORI}

\section{A. Pemasaran}

Kotler (2008), mengemukakan definisi pemasaran berarti bekerja dengan pasar sasaran untuk mewujudkan pertukaran yang potensial dengan maksud memuaskan kebutuhan dan keinginan manusia. Sehingga dapat dikatakan bahwa keberhasilan pemasaran merupakan kunci kesuksesan dari suatu perusahaan. Menurut Stanton (2004), definisi pemasaran adalah suatu sistem keseluruhan dari kegiatan-kegiatan bisnis yang ditujukan untuk merencanakan, menentukan harga, mempromosikan dan mendistribusikan barang atau jasa yang memuaskan kebutuhan baik kepada pembeli yang ada maupun pembeli potensial.

\section{B. Bauran Pemasaran}

Menurut Hammel dan Prahalad dalam Suyanto (2007) menyatakan bahwa tujuan dari strategi tidak hanya meniru produk, proses dan metode pesaing, melainkan mengembangkan untuk menciptakan peluang masa yang akan datang dan mengeksploitasinya. Strategi pemasaran dapat terpenuhi dengan penyediaan suatu sarana yang disebut dengan Marketing Mix. Marketing Mix ini merupakan inti dari sistem pemasaran perusahaan.
Menurut Hurriyati (2008), menyatakan bahwa bauran pemasaran merupakan unsur-unsur pemasaran yang saling terkait, dibaurkan, diorganisir, dan digunakan dengan tepat, sehingga perusahaan dapat mencapai tujuan pemasaran dengan efektif, sekaligus memuaskan kebutuhan dan keinginan konsumen. Menurut Kotler (2008), menyatakan bahwa Marketing Mix merupakan seperangkat alat pemasaran yang digunakan perusahaan untuk terus menerus mencapai tujuan pemasaranya di pasar sasaran. Mc Carthy dalam Kotler dan Keller (2008), mengklasifikasikan Marketing Mix menjadi empat besar kelompok yang disebut dengan $4 \mathrm{P}$ tentang pemasaran yaitu Product (produk), Price (harga), Place (tempat) dan promotion (promosi)

\section{Komponen Bauran Pemasaran}

Kotler dan Keller (2008), mengklasifikasikan Marketing Mix menjadi empat besar kelompok yang disebut dengan $4 \mathrm{P}$ tentang pemasaran yaitu Product (produk), Price (harga), Place (tempat) dan promotion (promosi). Adapun uraian dari komponen bauran pemasaran tersebut adalah sebagai berikut :

\section{Product (produk)}

Menurut Kotler dan Keller (2008), menyatakan bahwa produk adalah segala sesuatu yang dapat ditawarkan ke pasar untuk memenuhi kebutuhan dan keinginan konsumen. Keputusan tentang produk ini mencakup penentuan bentuk penawaran secara fisik, merknya, pembungkus, garansi dan servis sesudah penjualan. Pengembangan produk dapat dilakukan setelah menganalisa kebutuhan dan keinginan pasarnya. Jika msalah ini telah diselesaikannya, maka keputusan-keputusan tentang harga, distribusi dan promosi dapat diambil.

\section{Price (harga)}

Menurut Kotler dan Keller (2008), menyatakan bahwa harga adalah elemen dalam bauran pemasaran yang tidak saja menentukan profitabilitas tetapi juga sebagai sinyal untuk mengkomunikasikan proporsi nilai suatu produk. Pemasaran produk perlu memahami aspek psikologis dari informasi harga yang meliputi harga referensi (reference price), inferensi kualitas berdasarkan harga (price quality inferences) dan petunjuk harga (price clues). Pada setiap produk atau jasa yang ditawarkan, bagian pemasaran berhak menentukan harga pokoknya. Faktor-faktor yang perlu dipertimbangkan dalam penetapan harga tersebut antara lain biaya, keuntungan, praktik saingan dan perubahan 16 keinginan pasar. Kebijaksanaan harga ini menyangkut pula penetapan jumlah potongan, mark-up, mark-down, dan sebagainya

3. Place (tempat) 
Ada tiga aspek pokok yang berkaitan dengan keputusan-keputusan tentang distribusi (tempat), aspek tersebut adalah :

a. Sistem transportasi perusahaan, termasuk dalam sistem ini antara lain keputusan tentang pemilihan alat transportasi (pesawat udara, kereta api, kapal, truk, pipa), penetuan jadwal pengiriman, penentuan rute yang harus ditempuh dan seterusnya.

b. Sistem penyimpanan, dalam sistem ini bagian pemasaran harus menentukan letak gudang, jenis peralatan yang dipakai untuk menangani material maupun peralatan lainnya.

c. Pemilihan saluran distribusi, menyangkut keputusan-keputusan tentang penggunaan penyalur (pedagang besar, pengecer, agen, makelar), dan bagaimana menjalin kerjasama yang baik dengan para penyalur tersebut.

4. promotion (promosi).

Menurut Kotler dan Keller (2008), menyatakan bahwa promosi adalah berbagai cara untuk menginformasikan, membujuk, dan mengingatkan konsumen secara langsung maupun tidak langsung tentang suatu produk atau brand yang dijual. Bentuk-bentuk dari promosi atau yang dikenal dengan bauran promosi (promotion mix) adalah periklanan, promosi penjualan, public relation, direct marketing dan personal selling.

\section{Pemasaran Interaktif}

Menurut Yuliana (2007) di dalam kegiatan pemasaran interaktif konsumen tidak hanya bertindak sebagai peserta pasif yang menerima iklan sebelum melakukan pembelian, tetapi juga proaktif dan interaktif dalam kegiatan pemasaran. Tujuan dari pemasaran interaktif adalah untuk memikat dan memelihara konsumen yang akan menjadi rekan bisnis dalam penciptaan, pembelian, dan pengembangan produk serta layanan, dan salah satu media yang paling efektif untuk melakukan kegiatan pemasaran interaktif adalah melalui social networking websites. Dengan aktifnya konsumen maka feedback yang didapat oleh penjual adalah berupa masukan dalam pengembangan produk apa saja selanjutnya agar konsumen akan kembali membeli lagi di tempat penjual. Selain itu testimoni yang diberikan oleh konsumen yang sudah pernah membeli juga akan menjadi pertimbangan untuk menarik para konsumen baru.

\section{E. Perilaku Konsumen}

Perilaku mengacu pada efek behavioral yang dapat diamati berupa: pola-pola tindakan, kegiatan dan kebiasaan yang dibuat. Dalam membahas Behavior yang berarti tingkah laku, tidak terlepas pada suatu aliran "Behaviorisme", yaitu suatu aliran psikologis yang mempelajari "Tingkah laku yang nyata, terbuka dan dapat diukur secara obyektif" (Singgih, 2008). Definisi tersebut memberikan pengertian bahwa manusia merupakan kesatuan jiwa raga yang tidak terpisahkan, melainkan dorongan yang bersumber dari kebutuhan dasarnya sebagai penggerak untuk mempertahankan kelangsungan hidupnya dan berinteraksi dengan lingkungan.

Menurut Kamus Umum Bahasa Indonesia W. J. S .Purwadarminto (2009), mengemukakan bahwa perilaku adalah "Tanggapan atau reaksi yang terwujud dalam gerakan atau sikap, tidak saja badan atau ucapan“. Sedangkan menurut Purwanto (2010), perilaku adalah "segala tindakan atau perbuatan manusia yang kelihatan atau yang tidak kelihatan, yang disadari maupun yang tidak disadari, termasuk didalamnya cara berbicara, berjalan, berfikir, cara melakukan sesuatu yang datangnya dari luar diri maupun dari dalam diri“. Jadi dapat dikatakan bahwa perilaku adalah merupakan cerminan dari pengetahuan, sikap dan ditunjukan dengan tindakan atau perbuatan.

Perilaku konsumen (consumer behavior) dapat didefinisikan sebagai kegiatan-kegiatan individu yang secara langsung terlibat dalam mendapatkan dan mempergunakan barang-barang dan jasa-jasa, termasuk didalamnya proses pengambilan keputusan pada persiapan dan penentuan kegiatan-kegiiatan tersebut (Dharmmesta \& Handoko, 2008). Ada dua elemen penting dari arti perilaku konsumen: (1) proses pengambilan keputusan, dan (2) kegiatan fisik, yang semua itu melibatkan individu dalam menilai, mendapatkan, dan mempergunakan barang-barang dan jasa-jasa ekonomis.

\section{F. Impulse Buying (Pembelian Tidak Terencana)}

Pemahaman tentang konsep pembelian impulsif (impulsive buying) dan pembelian tidak direncanakan (unplanned buying) oleh beberapa peneliti tidak dibedakan. Philipps dan Bradshow (1993) dalam semuel (2006), tidak membedakan antara unplanned buying dengan impulsive buying, tetapi memberikan perhatian penting kepada periset, pelanggan harus memfokuskan pada interaksi antara point-of-sale dengan pembeli yang sering diabaikan.

Engel, Blacwell dalam Semuel (2006), mendefinisikan pembelian tidak terencana adalah suatu tindakan pembelian yang dibuat tanpa direncanakan terlebih sebelumnya atau keputusan pembelian dilakukan pada saat berada di dalam toko. Cobb, Hayer dalam Semuel (2006), mengklasifikasikan suatu pembelian impulsif terjadi apabila tidak terdapat tujuan pembelian merek tertentu atau kategori produk tertentu pada saat masuk ke dalam toko. 
Sedangkan menurut Loudon dan Bitta (1993), "Impulse buying or unplanned purchasing is another consumer purchasing pattern. As the term implies, the purchase that consumers do not specifically planned". Ini berarti bahwa impulse buying merupakan salah satu jenis perilaku konsumen, dimana hal tersebut terlihat dari pembelian konsumen yang tidak secara rinci terencana.

Pernyataan tersebut didukung oleh Iyer (fadjar, 2007), impulse buying adalah suatu fakta kehidupan dalam perilaku konsumen yang dibuktikan sebagai suatu kegiatan pembelian yang berhubungan dengan lingkungan dan keterbatasan waktu dalam berbelanja, dimana rute pembelian yang mereka lakukan semestinya berbeda. Rute tersebut dapat dibedakan melalui hirarki impulse yang memperlihatkan bahwa perilaku didasarkan pada respon afektif yang dipengaruhi oleh perasaan yang kuat (Mown dan Minor, 2002), sehingga impulse bauying menurut Hoch et al., terjadi ketika terdapat perasaan positif yang sangat kuat yang kemudian diikuti oleh sikap pembelian (Negara dan Dharmmesta, 2003).

Kollat, Willet dalam Semuel (2006), memperkenalkan Tipologi perencanaan masuk toko, meliputi perncanaan terhadap produk dan merek produk, kategori produk, kelas produk, kebutuhan umum yang ditetapkan, kebutuhan umum yang belum ditetapkan.

Beberapa peneliti pemasaran beranggapan bahwa impulse sinonim dengan unplanned ketika para psikolog dan ekonom memfokuskan pada aspek irasional atau pembelian impulsif murni (Bayley dan Nancarrow dalam Semuel, 2006). Thomson et al dalam Semuel (2006) mengemukakan bahwa ketika terjadi pembelian impulsif akan memberikan pengalaman emosional lebih dari pada rasional, sehingga tidak dilihat sebagai suatu sugesti, dengan dasar ini maka pembelian impulsif lebih dipandang sebagai keputusan rasional dibanding irasional. Adapun tipe-tipe dari pembelian tidak terncana menurut David Loudon, Albert J Della Bitta , Hawkins Stren (Fadjar, 2007) :

\section{Pure Impulse (pembelian Impulsif murni)}

Sebuah pembelian menyimpang dari pola pembelian normal. Tipe ini dapat dinyatakan sebagai novelty / escape buying.

2. Suggestion Impulse (Pembelian impulsif yang timbul karena sugesti)

Pada pembelian tipe ini, konsumen tidak mempunyai pengetahuan yang cukup terlebih dahulu tentang produk baru, konsumen melihat produk tersebut untuk pertama kali dan memvisualkan sebuah kebutuhan untuk benda tersebut.

3. Reminder Impulse (pembelian impulsif karena pengalaman masa lampau)
Pembeli melihat produk tersebut dan diingatkan bahwa persediaan di rumah perlu ditambah atau telah habis.

4. Planned Impulse (Pembelian impulsif yang terjadi apabila kondisi penjualan tertentu diberikan)

Tipe pembelian ini terjadi setelah melihat dan mengetahui kondisi penjualan. Misalnya penjualan produk tertentu dengan harga khusus, pemberian kupon dan lain-lain.

Engel, Blackwell, dan Miniard (Fadjar, 2007), menyatakan bahwa suatu pembelian dapat direncanakan dalam suatu pengertian walaupun niat yang pasti tidak dinyatakan secara verbal atau secara tertulis pada daftar belanja. Berdasarkan penelitian Rook dan Fisher (Negara dan Dharmmesta, 2003), bahwa pembelian bardasarkan impulse terjadi katika konsumen mengalami desakan tiba-tiba, yang biasanya sangat kuat dan menetap untuk membeli sesuatu dengan segera.

Menurut Rook dan Fisher (Stanton, 1998), pembelian tidak terencana (impulse buying) memiliki beberapa karakteristik, yaitu sebagai berikut :

\section{Spontanitas}

Pembelian ini tidak diharapkan dan memotivasi konsumen untuk membeli sekarang, sering sebagai respons terhadap stimulasi visual yang langsung ditempat penjualan.

2. Kekuatan, kompulsi, dan intensitas

Mungkin ada motivasi untuk mengesampingkan semua yang lain dan bertindak seketika.

3. Kegairahan dan stimulasi

Desakan mendadak untuk membeli sering disertai emosi yang dicirikan sebagai "menggairahkan","menggetarkan" atau "liar".

4. Ketidak pedulian akan akibat

Desakan untuk membeli dapat menjadi begitu sulit ditolak sehingga akibat yang mungkin negatif diabaikan.

\section{G. Periklanan}

Iklan adalah sarana promosi yang digunakan oleh perusahaan guna menginformasikan, menarik dan memengaruhi calon konsumennya. Penggunaan promosi melalui iklan dapat dilakukan melalui berbagai media, seperti :
a. Pemasangan billboard dijalan-jalan strategis
b. Pencetakan brosur, baik disebarkan di setiap cabang atau pusat-pusat perbelanjaan
c. Pemasangan spanduk dilokasi yang strategis pemasangan iklan melalui Koran
d. Pemasangan iklan melalui majalah
e. Pemasangan iklan melalui televisi dan
f. Pemasangan iklan melalui radio. 
Tujuan pengunaan dan pemilikan media iklan tergantung dari tujuan perusahaan. Tujuan penggunaan iklan sebagai media promosi, adalah sebagai berikut :

a. Untuk pemberitahuan tentang segala sesuatu yang berkaitan dengan produk yang dimiliki oleh suatu perusahaan, seperti peluncuran produk baru, keuntungan dan kelebihan suatu produk atau informasi lainnya.

b. Untuk mengingat kembali nasabah tentang keberadaan atau keunggulan produk yang ditawarkan.

c. Untuk memperhatikan dan minat para pelanggan baru dengan harapan akan memperoleh daya tarik dari calon pelanggan.

d. Memngaruhi nasabah saingan agar berpindah ke perusahaan yang mengiklankan.

\section{H. Periklanan Menggunkan Internet}

Periklanan internet (internet advertising) adalah salah satu periklanan yang banyak dipakai perusahaan-perusahaan dalam mempromosikan produk mereka. Pada saat ini internet bukan lagi hal yang asing bagi masyarakat, penggunaan internet diklaangan masyarakat yang meningkat membuat perusahaan untuk memasang iklan pada website publisher yang potensial. Internet memberikan pengaruh secara radikal bagaimana perusahaan berkomunikasi dengan pelanggan atau membangun hubungan diantara mereka (Sumarwan, et. All, 2010).

Internet dapat membuat pengguannya (konsumen) mengontrol sendiri informasi apa yang akan mereka lihat dan seberapa lama mereka ingin melihat informasi tersebut. Dengan hal ini maka pengguana internet dapat memlih situs mana yang akan mereka buka selanjutnya, serta keputusankeputusan lain yang dapat mereka tentukan pada saat mereka menggunakan internet. Dimana hal ini mungkin sulit dilakukan oleh iklan televisi (Pramoto dan Hardianto, 2008)

\section{Bntuk-bentuk Periklanan Menggunakan Internet}

Bentuk periklanan internet pada awalnya hanya membentuk banner yang dipasang di beberapa website. Seiring dengan perkembangan teknologi dan kebutuhan pengguan internet akan informasi. Bentuk periklanan internet dapat dikelompokan sebagai berikut :

1. Direct Advertisting, dimana pemasangan iklan dan pemilik media berhubungan lansung dan menandatangani kontrak untuk menampilkan iklan atau inisiatif lainnya.

2. Self-service adveristing: pendekatan iklan baru dimana materi iklan, penempatan iklan, tampilan serta teks dikerjakan sendiri oleh pemasang iklan melalui metode proses yang dilakukan sendiri di online. Contoh : Blogads dan Adwords

3. Ad Network: sebuah jaringan (network) iklan yang menghubungkan dan memediasi antara pemasangan iklan dan pemilik situs web. Contoh: ValueClikMedia dan tribal Fusion.

4. Contextual Advertisting: iklan yang ditargetkan pada konten. Iklan tidak ditampilkan secara random, tetapi iklan telah dipilih secara otomatis sesuai dengan konten yang relevan dengan iklan tersebut. Contoh: Google AdSense Yahoo Publisher Network

5. Twitter Adveristing: iklan yang berfungsi sebagai tweet dari pemasang iklan, yaitu iklan berbasis keyword yang pendek, yang diidstribusikan kepada user yang membaca konten yang sesuai dengan keyword yang dipilih. Contoh: Magpie dan Twittand

6. In-Teks Advertising: system In-Teks advertising secar otomatis menghubungkan kata-kata tertentu didalam website dengan konten iklan yang berhubungan. Contoh: kontera dan Vibrant in-text ad

7. Ad network optimization: jasa optimasi iklan ini mengevaluasi dan memilih iklan yang membayar terbanyak untuk ditampilakn dengan halaman web dengan mengevaluasi semua pilihan serta ukuran iklan yang paling bak, dan karakteristik visualnya. Contoh: PubMatic da YieldBuild.

8. Rep Ad Agencies: egen periklanan yang mewakili bolg-blog serta situs web tertentu dan memediasi penjualan mereka untuk kampanye-kampanye besar yang dilakukan barand-brand besar ataupun agensi iklan besar. Contoh: Fedrated Media dan Tribal Fusion

9. Social advertisting: iklan untuk social media. Tidak seperti iklan tradisional, format iklan ini menggunakan dinamika pengaruh social seperti pengaruh per group, word of mounth, viral marketing dan rekomendasi lansung dari teman ke teman. Contoh: VideoEgg dan Meebo.

10. Vieo Advertising: bentuk iklan yang ditargetkan pada konten video. Berbagai format tersedia, termasuk iklan dinamis yang bisa tampil sebelum, setelah ataupun selama tayangan konten video tertentu. Contoh: Voxan dan AdSense for Video

11. RSS Advertisng: iklan ini ditampilkan dalam RSS Feed, yang bisa disesuaikan dengan konteks konten RSS fee tersebut atau secara manual ditargetkan pada kebutuhan promosi tertentu. Contoh; Pheedo dan Feedvertising. 
12. Sponshorship: adalah bentuk bantuan dana atau bisa juga dalam bentuk produk/layanan sebagai ganti promosi terhadap suatu brand.

\section{J. Efektivitas Periklanan Menggunakan Internet}

Menurutut Kotler dan Amstrong (2010), pada saat ini iklan internet telah menjadi kekuatan, pendorong bagi inisiatif dan upaya periklanan. Seiring dengan pengguanan internet yang semakin luas mendorong transaksi online semakin luas juga, dan bahkan menjadi media pemasang iklan bagi produk yang dipasarkan. Para pemasang iklan (advertiser) akan memasangkan iklannya pada website-website publisher yang potensial, yakni banyak dikunjungi oleh pengunjung (visitor).

Menurut Tsang dan Tse dalam Wei, Jerome, dan Shan (2010) iklan internet yang efektif adalah iklan internet yang dapat memberikan respon lansung dari konsumen. Dalam memberikan respon lansung dari konsumen, suatu periklanan internet dilengkapi beberapa fitur untuk mendukungnya, berdasarkan model dari Burke dan Edell (1998) dan Escalas dan Rutgers (2003) terdapat 3 fitur online yang digunakan dalam iklan internet, yakni Multimedia, Picture, dan Content.

\section{K. Promosi Penjualan}

Wells, Burnett dan Manarty (2008), promosi penjualan merupakan upaya pemasaran yang bersifat media dan non media untuk merangsang coba-coba dari konsumen, meningatkan permintaan dari konsumen atau untuk memperbaki kualitas produk. Dua teori yang berkaitan dengan promosi penjualan adalah level of adaptation dan threshold level. Tingkat adaptasi (level of adaptation) akan terjadi pada konsumen jika promosi penjualan dilakukan terlalu sering. Konsumen akan terbiasa dengan promosi penjualan sehingga respon kegiatan promosi penjualan akan cenderung sama dengan respon terhadap kegiatan yang bukan promosi penjualan. Tingkat ambang batas (threshold level) merupakan batas konsumen akan mempunyai respons terhadap suatu aktivitas tertentu. Threshold level yang dibutuhkan untuk bisa menarik perhatian konsumen semakin tinggi jika promosi penjualan dibuka terus menerus.

Wells, Burnett dan Manarty (2008), mengatakan bahwa promosi penjualan menawarkan insentif ekstra agar konsumen melakukan tindakan. Potongan harga, hadiah, program berkelanjutan adalah insentif ekstra agar konsumen mau melakukan tindakan, paling tidak punya perhatian terhadap produk yang ditawarkan.

\section{Peran Promosi Penjualan}

Promosi penjualan sangat memiliki andil besar dalam proses pemasaran. Secara umum terdapat tiga tujuan dari promosi penjualan yaitu :

1. merangsang permintaan oleh pengguna industri atau konsumen rumah tangga.

2. memperbaiki kinerja pemasaran dari penjualan kembali

3. sebagai suplemen periklanan, penjualan tata muka, hubungan masyarakat, dan pemasaran langsung.

Secara spesifik, tujuan promosi penjualan hampir sama dengan periklanan yaitu agar konsumen mau mencoba pengguanaan produk, mendorong peningkatan pengeluaran sepanjang masa liburan, dan mendorong konsumen yang sudah ada agar menggunakan produk lebih sering lagi

\section{Tipe-tipe Promosi Penjualan}

Wells, Burnett dan Manarty (2008), mengatakan bahwa terdapat tipe-tipe promosi penjualan, yaitu:

1. Promosi penjualan bagi konsumen akhir

a. Potongan harga, Potongan harga adalah pengurangan harga produk dari harga normal dalam periode tertentu.

b. Kupon Istilah kupon maknanya sama dengan voucer. Keduanya merupakan tanda bukti utang yang diberikan oleh produsen. Artinya, pada kupon atau voucers tersebut produsen menyatakan punya hutang sejumlah tertentu dan akan dibayar jika konsumen membeli produk yang ditawarkanya.

c. Kontes dan Undian Kontes adalah jenis promosi penjualan yang sering dipakai oleh pemasar. Prakteknya, beberapa peserta harus menyelesaikan tugas tertentu. Kontes dan undian/kuis yang baik biasanya menghasilkan tingkat keterlibatan yang tinggi dari konsumen. misalnya peserta kuis diminta menyebutkan kandungan kalsium, peserta kuis tentu saja harus mencari dan membaca tingkat kandungan kalsium pada label produk.

d. Program berkelanjutan (Continuity Programs) Program berkelanjutan ini berupa pemberian hadiah berjenjang jika konsumen melakukan pembelian yang lebih tinggi. Semakin tinggi jumlah pembelian semakin besar nilai hadiah yang bisa diperoleh.

2. Pemberian penawaran premium yaitu pemberian imbalan yang berwujud dari pemasar karena penggunaan produk atau mengunjungi tempat penjualan. Pemberian imbalan tersebut bisa secara langsung atau tidak langsung. Terdapat empat tipe pemberian hadiah langsung seperti : 
a. Soter premium, memberikan hadiah pada konsumen di tepat dimana konsumen membeli barang

b. In pack, memasukan hadiah dalam kemasan sejak dari pabrik

c. On pack, menempatkan hadiah di luar kemasan dari pabrik

d. Container premium kemasan itu sendiri sebagai premium

3. Rabat. Rabat merupakan salah satu teknik refund (pengembalian) dalam promosi penjualan. Refund berarti pemasaran mengembalikan uang kepada konsumen yang telah dibayarkan untuk membeli produk. Rabat biasanya dihubungkan dengan jumlah pembelian dan periode pembelian.

4. Periklanan khusus Periklanan khusus hampir sama dengan premium, kecuali konsumen tidak harus membeli apapun agar bisa menerima item khusus (hadiah). Disebut periklanan khusus karena kegiatanya biasanya diselenggarakan sesuai dengan kegiatan tahunan.

5. Sampel gratis. pemberian sampel gratis merupakan cara yang paling mudah agar konsumen potensial mempunyai pengalaman atas penggunaan produk yang ditawarkan.

\section{METODE PENELITIAN}

Penelitian ini merupakan penelitian yang mengguanakan pendekatan kuantitatif yaitu pendekatan ilmiah terhadap pengambilan keputusan manajerial dan ekonomi, dalam penelitian ini berdasarkan data-data yang diperoleh dari wawancara dan kuisioner. Dan berdasarkan jenis penelitian ini merupakan penelitian ex-post facto, karena didalam penelitian ini tidak dibuat perlakuan atau manipulasi terhadap variabelnya tetapi mengungkap berdasarkan gejala yang telah ada pada diri responden. Penelitian ini menggunakan teknik Non Probability Sampling dengan cara Sampling Purposive. Dimana peneliti menggunakan pertimbangan sendiri secara sengaja dalam memilih anggota populasi yang dianggap sesuai dalam memberikan informasi yang dibutuhkan untuk penelitian. Penelitian ini menggunakan variable bebas dan terikat. Variabel bebas (independent variabel), yaitu variabel yang mendahului atau mempengaruhi variabel terikat. Variabel bebas dalam penelitian meliputi: Periklanan $\left(\mathrm{X}_{1}\right)$ dan Promosi penjualan $\left(\mathrm{X}_{2}\right)$. Variabel terikat (dependent variabel), merupakan variabel terikat akibat atau tergantung pada variabel yang mendahuluinya. Dalam penelitian ini yang menjadi variabel terikat adalah perilaku pembelian tidak terencana $(\mathrm{Y})$. Metode pengumpulan data menggunakan dokumentasi dan kuisioner.

\section{HASIL DAN PEMBAHASAN}

A. Deskripsi Data Variabel

\section{a) Variabel Periklanan (X1)}

Adapun distribusi jawaban responden pada variabel X1 disajikan pada tabel berikut:

Tabel 1.

Distribusi Jawaban Responden Variabel (X1)

\begin{tabular}{|c|c|c|c|c|c|c|c|c|c|c|c|c|}
\hline \multirow[t]{3}{*}{ Pernyataan } & \multicolumn{10}{|c|}{ Jawaban } & \multirow{2}{*}{\multicolumn{2}{|c|}{ Total }} \\
\hline & \multicolumn{2}{|c|}{ SS } & \multicolumn{2}{|l|}{$\mathbf{S}$} & \multicolumn{2}{|l|}{$\mathbf{N}$} & \multicolumn{2}{|l|}{ TS } & \multicolumn{2}{|c|}{ STS } & & \\
\hline & $\mathbf{F}$ & $\%$ & $\mathbf{F}$ & $\%$ & $\mathbf{F}$ & $\%$ & $\mathbf{F}$ & $\%$ & $\mathbf{F}$ & $\%$ & $\mathbf{F}$ & $\%$ \\
\hline X1.1 & 8 & $8 \%$ & 44 & $44 \%$ & 29 & $29 \%$ & 18 & $18 \%$ & 1 & $1 \%$ & 100 & $100 \%$ \\
\hline $\mathbf{X 1 . 2}$ & 10 & $10 \%$ & 17 & $17 \%$ & 36 & $36 \%$ & 36 & $36 \%$ & 1 & $1 \%$ & 100 & $100 \%$ \\
\hline $\mathbf{X 1 . 3}$ & 6 & $6 \%$ & 30 & $30 \%$ & 46 & $46 \%$ & 18 & $18 \%$ & 0 & $0 \%$ & 100 & $100 \%$ \\
\hline X1.4 & 14 & $14 \%$ & 37 & $37 \%$ & 37 & $37 \%$ & 12 & $12 \%$ & $\mathrm{O}$ & $\%$ & 100 & $100 \%$ \\
\hline
\end{tabular}

Tabel diatas menunjukkan bahwa untuk pernyataan X1.1 sebagian besar responden menjawab seruju (S) sebanyak 44 responden (44\%). Kemudian untuk prnyataan X1.2 sebagian besar responden menjawab netral (N) dan tidak setuju yakni frekuensinya sama sebanyak 36 responden (36\%). Lalu untuk pernyataan X1.3 sebagian besar responden menjawab netral $(\mathrm{N})$ yakni sebanyak 46 responden
(46\%) dan yang terakhir untuk pernyataan X1.4 sebagian besar responden menjawab setuju (S) dan netral $(\mathrm{N})$ yakni frekuensinya sama yakni sebesar 37 responden (37\%).

\section{2) Variabel Promosi Pejualan (X2)}

Adapun distribusi jawaban responden untuk variabel promosi penjualan (X2) disajikan pada tabel dibawah ini:

Tabel 2.

Distribusi Jawaban Responden Variabel (X2)

\begin{tabular}{|c|c|c|c|c|c|c|c|c|c|c|c|c|}
\hline \multirow[t]{3}{*}{ Pernyataan } & \multicolumn{10}{|c|}{ Jawaban } & \multirow{2}{*}{\multicolumn{2}{|c|}{ Total }} \\
\hline & \multicolumn{2}{|c|}{ SS } & \multicolumn{2}{|l|}{$\mathbf{S}$} & \multicolumn{2}{|l|}{$\mathbf{N}$} & \multicolumn{2}{|c|}{ TS } & \multicolumn{2}{|c|}{ STS } & & \\
\hline & $\mathbf{F}$ & $\%$ & $\mathbf{F}$ & $\%$ & $\mathbf{F}$ & $\%$ & $\mathbf{F}$ & $\%$ & $\mathbf{F}$ & $\%$ & $\mathbf{F}$ & $\%$ \\
\hline
\end{tabular}




\begin{tabular}{|l|l|l|l|l|l|l|l|l|l|l|l|l|}
\hline X2.1 & 36 & $36 \%$ & 31 & $31 \%$ & 25 & $25 \%$ & 6 & $6 \%$ & 2 & $2 \%$ & 100 & $100 \%$ \\
\hline X2.1 & 39 & $39 \%$ & 30 & $30 \%$ & 23 & $23 \%$ & 8 & $8 \%$ & 0 & $0 \%$ & 100 & $100 \%$ \\
\hline X2.3 & 36 & $36 \%$ & 37 & $37 \%$ & 21 & $21 \%$ & 6 & $6 \%$ & 0 & $0 \%$ & 100 & $100 \%$ \\
\hline $\mathbf{X 2 . 4}$ & 22 & $22 \%$ & 32 & $32 \%$ & 30 & $30 \%$ & 10 & $10 \%$ & 6 & $6 \%$ & 100 & $100 \%$ \\
\hline
\end{tabular}

\section{Sumber: Data diolah SPSS 18}

Tabel diatas menunjukkan bahwa pernyataan X2.1 sebagian responden menjawab sangat setuju (ST) sebanyak 36 ressponden (36\%). kemudian item pernyataan X2.2 sebagian besar responden menjawab sangat setuju (ST) yakni sebanyak 39 responden (39\%). Kemudian item pernyataan X2.3 sebagian besar responden menjawab setuju (S) sebanyak 37 responden (37\%). Dan yang terakhir untuk item pernyataan X2.4 sebagian besar responden menjawab setuju (S) yakni sebanyak 32 responden (32\%).

\section{3) Variabel Pembelian Tidak Terencana (Y)}

Adapun distribusi jawaban responden untuk variabel pembelian tidak terencana $(\mathrm{Y})$ disajikan pada tabel dibawah ini:

Tabel 3.

Distribusi Jawaban Responden Variabel Y

\begin{tabular}{|c|c|c|c|c|c|c|c|c|c|c|c|c|}
\hline \multirow[t]{3}{*}{ Pernyataan } & \multicolumn{10}{|c|}{ Jawaban } & \multirow{2}{*}{\multicolumn{2}{|c|}{ Total }} \\
\hline & \multicolumn{2}{|c|}{ SS } & \multicolumn{2}{|c|}{$\mathbf{S}$} & \multicolumn{2}{|c|}{$\mathbf{N}$} & \multicolumn{2}{|c|}{ TS } & \multicolumn{2}{|c|}{ STS } & & \\
\hline & $\mathbf{F}$ & $\%$ & $\mathbf{F}$ & $\%$ & $\mathbf{F}$ & $\%$ & $\mathbf{F}$ & $\%$ & $\mathbf{F}$ & $\%$ & $\mathbf{F}$ & $\%$ \\
\hline Y1 & 7 & $7 \%$ & 46 & $46 \%$ & 42 & $42 \%$ & 5 & $5 \%$ & o & O\% & 100 & $100 \%$ \\
\hline Y2 & 14 & $14 \%$ & 44 & $44 \%$ & 34 & $34 \%$ & 8 & $8 \%$ & $\mathrm{O}$ & $0 \%$ & 100 & $100 \%$ \\
\hline
\end{tabular}

Tabel diatas menunjukkan bahwa untuk pernyataan Y1 sebagian besar responden menjawab setuju (S) sebanyak 46 responden (46\%). Dan untuk item pernyataan Y2 sebagian besar responden menjawab setuju (S) yakni sebesar 44 responden (44\%).

\section{B. Hasil Instrumen Penelitian}

\section{1) Hasil Uji Validitas}

Uji validitas dilakukan untuk menguji keabsahan masing-masing pertanyaan atau pernyataan variabel dalam penelitian ini. Nilai validitas ditunjukkan dengan nilai $r$-hitung lebih besar atau sama dengan r-tabel maka dengan begitu pernyataan dianggap valid. Sebaliknya jika nilai $r$ hitung lebih kecil dari r-tabel maka dianggap tidak valid. Nilai $r$-tabel didalam distribusi $R$ dengan $\alpha$ : 0,05 dan df (n-2): 98 adalah sebesar 0.1654. adapun hasil uji validitas untuk masing-masing pernyataan untuk masing-masing variabel penelitian ini disajikan pada tabel berikut ini:

Tabel 4.

Hasil Uji Validitas

\begin{tabular}{|c|c|c|c|c|}
\hline Variabel & Pernyataan & r-hitung & r-tabel & Ket. \\
\hline \multirow{4}{*}{$\begin{array}{l}\text { Periklanan } \\
\quad(\mathrm{X} 1)\end{array}$} & 1 & 0.648 & 0.165 & Valid \\
\hline & 2 & 0.684 & 0.165 & Valid \\
\hline & 3 & 0.724 & 0.165 & Valid \\
\hline & 4 & 0.719 & 0.165 & Valid \\
\hline \multirow{4}{*}{$\begin{array}{l}\text { Promosi } \\
\text { Penjualan } \\
\text { (X2) }\end{array}$} & 1 & 0.685 & 0.165 & Valid \\
\hline & 2 & 0.824 & 0.165 & Valid \\
\hline & 3 & 0.792 & 0.165 & Valid \\
\hline & 4 & 0.796 & 0.165 & Valid \\
\hline \multirow{2}{*}{$\begin{array}{l}\text { Pembelian } \\
\text { Tidak } \\
\text { Terencana } \\
\text { (Y) }\end{array}$} & 1 & 0.819 & 0.165 & Valid \\
\hline & 2 & 0.872 & 0.165 & Valid \\
\hline
\end{tabular}

Sumber: Data diolah SPSS 18

Tabel diatas menunjukkan bahwa semua item pernyataan untuk semua variabel yaitu variabel periklanan (X1), promosi penjualan (X2) dan variabel pembelian tidak terencana $(\mathrm{Y})$ dalam penelitian ini adalah valid karena seluruh item pernyataan memiliki nilai r-hitung lebbih besar dari r-tabel. Hal ini berarti pernyatan dalam koesioner yang dibagikan kepda responden dapat digunakan sebagai alat yang mampu mengukur hubungan periklanan dan promosi penjualan menggunakan internet terhadap perilaku pembelian tidak terencana studi kasus pada Mahasiswa dan Dosen Universitas Muhammadiah Mataram. 


\section{2) Hasil Uji Reliabilitas}

Uji reliabilitas adalah uji kehandalan atau kemampuan instrument dalam mengukur variabel yang akan diteliti. Nilai realibilitas ditunjukkan oleh

Tabel 5.

Hasil Uji Reliabilitas

\begin{tabular}{|c|l|c|c|c|}
\hline No & \multicolumn{1}{|c|}{ Variabel } & Cronbach's Alpa & Nilai Kritis & Reliabilitas \\
\hline $\mathbf{1}$ & Periklanan & 0,639 & 0,60 & Reliabel \\
\hline $\mathbf{2}$ & Promosi Penjualan & 0,773 & 0,60 & Reliabel \\
\hline 3 & $\begin{array}{l}\text { Pembelian Tidak } \\
\text { Terencana }\end{array}$ & 0,600 & 0,60 & Reliabel \\
\hline
\end{tabular}

Sumber: Data diolah SPSS 18

Tabel diatas menunjukkan bahwa nilai Cronbach's Alpa untuk variabel periklanan (X1) promosi penjualan (X2) dan pembelian tidak terencana (Y) lebih besar dari o,6o maka instrument yang digunakan dalam penelitian ini adalah handal atau reliabel. Hal ini berarti semua pernyataan dalam koesioner penelitian ini dapat digunakan untuk mengukur hasil penelitian agar tetap konsisten, jika dilakukan pengukuran dua kali atau lebih dengan mengguanakan alat ukur periklanan dan promosi penjualan terhadap perilaku pembelian tidak terencan maka hasil yang akan diperoleh akan tetap sama nilai Cronbach's Alpa, dengan ketentuan jika nilai Cronbach's Alpa lebih besar atau sama dengan o,60 maka instrument penelitian dianggap handal atau reliabel.

\section{Hasil Uji Asumsi Klasik 1) Hasil Uji Normalitas}

Uji normalitas dilakukan untuk menguji sebaran nilai residual atau nilai eror regresi yang dihasilkan. Regresi yang baik mensyaratkan nilai residual regresi terdistribusi secara normal. Uji normalitas menggunakan uji Kolmogrov-Smirnov $\mathrm{Z}$ dengan ketentuan jika nilai Asymp. Sig. (2-taild) lebih besar daripada 0,05 , maka residual regresi dianggap terdistribusi normal atau memenuhi asumsi normalitas. Sebaliknya jika nilai probabilitas lebih kecl daripada 0,05, maka nilai residual tidak terdistribusi normal.

Tabel 6.

Hasil Uji Normalitas

One-Sample Kolmogorov-Smirnov Test

\begin{tabular}{|c|c|c|}
\hline & & $\begin{array}{l}\text { Unstandardized } \\
\text { Predicted Value }\end{array}$ \\
\hline $\mathrm{N}$ & & 100 \\
\hline \multirow{2}{*}{ Normal Parameters ${ }^{\mathrm{a}, \mathrm{b}}$} & Mean & 7.1900000 \\
\hline & Std. Deviation & .62441810 \\
\hline \multirow[t]{3}{*}{ Most Extreme Differences } & Absolute & .088 \\
\hline & Positive & .055 \\
\hline & Negative & -.088 \\
\hline Kolmogorov-Smirnov Z & & .877 \\
\hline Asymp. Sig. (2-tailed) & & .425 \\
\hline
\end{tabular}

a. Test distribution is Normal.

b. Calculated from data.

Sumber: Data diolah SPSS 18

Hasil uji Kolmogorov-Smirnov Z merupakan nilai probabilitas (Asmp. Sig (2tailed) sebesar 0,425 lebih besar dari 0,05 maka dapat disimpulkan bahwa nilai residual regresi memenuhi asumsi normalitas atau terdistribusi secara normal. Hal ini berarti data variabel Periklanan (X1), Promosi penjualan (X2) dan Pembelian tidak terencana $(\mathrm{Y})$ dalam penelitian ini memiliki regresi yang baik untuk diteliti karena data yang diperoleh melalui penyebaran koesioner terdistribusi normal.

\section{2) Hasil Uji Multikolinearitas}

Uji multikolinearitas dilakukan untuk menguji apakah terjadi hubungan linier antar variabel independen (X) dalam sebuah penelitian. Syarat yang harus dipenuhi dalam regresi yang baik adalah tidak terjadi hubungan antar sesama variabel independen atau tidak terjadi multikolinearitas antar variabel independen mengacu pada nilai Tolerance dan nilai VIF dengan syarat jika nilai tolerance lebih besar daripada 0,1 dan nilai lebih kecil daripada 10 maka dikatakan tidak terdapat masalah multikolinieritas pada model regresi yang dihasilkan. 
Tabel 7.

Hasil Uji Multikolinearitas

Coefficients ${ }^{a}$

\begin{tabular}{|c|c|c|}
\hline \multirow{2}{*}{ Variabel } & \multicolumn{2}{|c|}{ Colliniearity Statistic } \\
\cline { 2 - 3 } & Tolerance & VIF \\
\hline Periklanan & .929 & 1.076 \\
\hline $\begin{array}{c}\text { Promosi } \\
\text { penjualan }\end{array}$ & .929 & 1.076 \\
\hline
\end{tabular}

Sumber: Data diolah SPSS 18

Berdasarkan tabel diatas dapat dilihat bahwa nilai VIF pada masing-masing variabel tidak ada yang melalui 10 dan nilai tolerance diatas 0,10 sehingga dapat disimpulkan dalam data ini tidak terjadi multikolinieritas. Hal ini berarti variabel independen yakni periklanan (X1) dan promosi penjualan dalam model regresi tidaak terjadi korelasi antar variabel tersebut sehingga dapat disimpulkan model regresi dalaa penelitian ini baik untuk dilakukan regresi linier berganda.

\section{3) Hasil Uji Hedrokodesitas}

Uji heterokedaasitas adalah uji ketiksamaan varian residual regresi antar satu pengamatan ke pengamatan lain atau dari satu responden ke respondenden lainnya. Regresi yang baik seharusnya tidak terjadi heterokedasitas. Hasil heterokedasitas dapat dilakukan dengan melihat grafik scatterplot, dengan ketentuan jika titik-titik resedul menyebar diatas dan dibawah titik nol maka resedul regresi bisa dikatakan tidak terjadi heterokedasitas.

\section{Gambar 1. \\ Hasil Uji Hetrokedesitas}

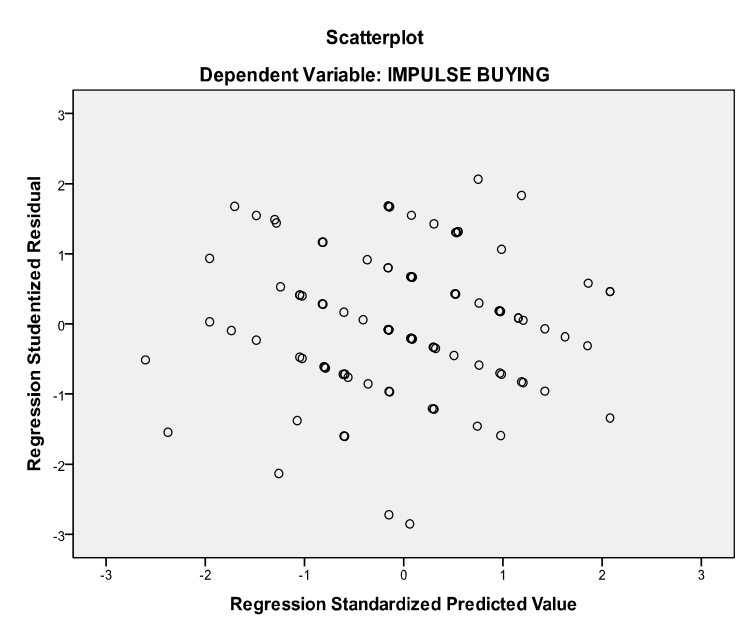

Sumber: Data diolah SPSS 18

Grafik scatterplot diatas menunjukkan titiktitik resedul regresi berada atau menyebar diatas dan dibawah titik o. Oleh karena itu dapat disimpulkan bahwa nilai residul regresi tidak terjadi perbedaan varian antar pengamatan atau tidak terjadi heterokedasitas. Hal ini berarti model regresi dari satu pengamatan ke pengamatan yang lain baik untuk dilakukan pengujian regresi linier berganda.

\section{Hasil Uji Regresi Linier Berganda}

Persamaan regresi menunjukkan nilai konstanta $(\alpha)$ dan nilai koefisien regresi $(\beta)$ pada masing-masing variabel. Nilai koefisien regresi besarnya perubahan nilai variabel dependen jika terjadi perubahan nilai variabel independen sedangkan nilai konstanta ( $\alpha$ ) menunjukkan besarnya nilai variabel dependen jika variabel indepeden bernilai o atau tidak ada.

Tabel 8.

Model Persamaan Regresi

Coefficients $^{\mathbf{a}}$

\begin{tabular}{|c|c|c|c|c|c|c|}
\hline \multirow{2}{*}{\multicolumn{2}{|c|}{ Model }} & \multicolumn{2}{|c|}{ Unstandardized Coefficients } & \multirow{2}{*}{$\begin{array}{c}\text { Standardized } \\
\text { Coefficients }\end{array}$} & \multirow[b]{2}{*}{$\mathrm{t}$} & \multirow[b]{2}{*}{ Sig. } \\
\hline & & $\bar{B}$ & Std. Error & & & \\
\hline 1 & (Constant) & 3.196 & .750 & & 4.259 & .000 \\
\hline & Periklanan & .137 & .048 & .263 & 2.857 & .005 \\
\hline & Promosi Penjualan & .142 & .038 & .341 & 3.697 & .000 \\
\hline
\end{tabular}

a. Dependent Variabel: Pembelian Tidak Terencana

Sumber: Data diolah SPSS 18

Berdasarkan tabel diatas maka diperoleh persamaan regresi sebagai berikut: $\mathrm{Y}=3.196+0,137 \mathrm{X} 1+0,142$

Interpretasi :

1. Konstanta $(\alpha)=3,196$, artinya jika variabel $\mathrm{X} 1$ dan X2 masing-masing bernilai o atau tidak ada maka niai variabel $\mathrm{Y}$ adalah sebesar 3.196.
2. Koefisien regresi $\mathrm{X} 1\left(\beta_{1}\right)=0,137$, artinya jika variabel $\mathrm{X} 1$ meningkat sebesar 1 poin maka variabel $\mathrm{Y}$ akan meningkat sebesar 0,137, dengan asumsi variabel X2 tetap konstan.

3. Koefisien regresi $X 2(\beta)=0,142$, artinya jika X2 meningkat sebesar 1 poin maka variabel Y akan meningkat sebesar 0,142, dengan asumsi variabel $\mathrm{X} 1$ tetap konstan. 
E. Hasil Uji Hipotesis

\section{1) Hasil Uji Parsial (Uji T)}

Uji T digunakan untuk menguji hipotesis apakah vriabel-variabel independen secara parsial atau secara terpisah berhubungan dengan variabel dependen. Adapun hipotesis yang diajukan dalam penelitian ini adalah sebagai berikut:

1. Ho: variabel $\mathrm{X}_{1}$ dan $\mathrm{X} 2$ secara parsial tidak memiliki berhubungan signifikan terhadap variabel Y.
2. Ha: variabel $\mathrm{X} 1$ dan $\mathrm{X} 2$ secara parsial memiliki berhubungan signifikan terhadap variabel $\mathrm{Y}$.

Adapun kriteria dalam pengambilan keputusan uji t ini adalah:

1. Jika t-hitung < t-tabel, maka Ho diterima dan $\mathrm{Ha}$ ditolak

2. Jika t-hitung > t-tabel, maka Ho ditolak dan Ha ditolak.

Nilai t-tabel diperoleh pada tabel distribusi $t$ dengan a: 0.05 dan df (n-2): 98 adalah sebesar 1,660. Adapun hasil uji t disajikan pada tabel di bawah ini:

Tabel 9.

Hasil Uji t

Coefficients $^{\mathbf{a}}$

\begin{tabular}{|c|c|c|c|c|c|}
\hline \multirow{2}{*}{ Model } & \multicolumn{2}{|c|}{} & Standardized \\
& \multicolumn{2}{|c|}{ Unstandardized Coefficients } & Coefficients & & \\
\cline { 2 - 5 } & $\mathrm{B}$ & Std. Error & Beta & $\mathrm{t}$ & Sig. \\
\hline 1 & 3.196 & .750 & & 4.259 & .000 \\
& (Constant) & .048 & .263 & 2.857 & .005 \\
Periklanan & .137 & .038 & .341 & 3.697 & .000 \\
\hline
\end{tabular}

a. Dependent Variabel: Pembelian Tidak Terencana

\section{Sumber: Data diolah SPSS 18}

1. Hubungan periklanan menggunakan internet terhadap perilaku pembelian tidak terencana

Diperoleh nilai t-hitung untuk variabel X1 sebesar 2,857 sedangkan nilai t-tabel pada alpa : 0,05 dan df: 98 sebesar 1,660. Karena nilai t-hitung lebih besar dari nilai t-tabel atau 2,857 > 1,660 maka keputusan yang diambil adalah Ho ditolak dan $\mathrm{Ha}$ diterima, variabel periklanan berhubungan secara signifikan terhadap pembelian tidak terencana.

2. Hubungan Promosi Penjualan Menggunakan

Internet Terhadap Pembelian Tidak Terencana

Diperoleh nlai t-hitung untuk variabel $\mathrm{X} 2$ sebesar 3,697 sedangkan nilai t-tabel pada alpha : o,05 dan df: 98 adalah sebesar 1,660. Karena nilai thitung lebih besar dari t-tabel atau 3,697>1,660 maka keputusan yang diambil adalah Ho ditolak dan $\mathrm{Ha}$ diterima, variabel promosi penjualan berhubungan signifikan terhadap pembelian tidak terencana.

\section{F. Hasil Uji Simultan (Uji F)}

Uji F dilakukan untuk mengetahui hubungan variabel-variabel independen secara simultan terhadap dependen. Adapun hipotesis simultan yang diajukan adalah:

1. Ho: $\beta 1=\beta 2$ : (variabel $\mathrm{X} 1$ dan $\mathrm{X} 2$ tidak memiliki hubungan signifikan terhadap variabel $\mathrm{Y}$ )

2. Ha: $\beta 1 \neq \beta 2$ : (variabel $\mathrm{X} 1$ dan $\mathrm{X} 2$ memiliki hubungna signifikan terhadap variabel $\mathrm{Y}$ )

Adapun kriteria pengambilan keputusannya adalah:

1. Jika F-hitung < F-tabel, maka Ho diterima.

2. Jika F-hitung $>$ F-tabel, maka Ho ditolak

Hasil Uji F disajikan pada tabel dibawah ini:

Tabel 10.

ANOVA $^{\mathrm{b}}$

Hasil Uji F

\begin{tabular}{|c|c|c|c|c|c|}
\hline Model & Sum of Squares & df & Mean Square & F & Sig. \\
\hline Regression & 38.600 & 2 & 19.300 & 14.765 &. .00 $^{\mathrm{a}}$ \\
Residual & 126.790 & 97 & 1.307 & & \\
Total & 165.390 & 99 & & & \\
\hline
\end{tabular}

a. Predictors: (Constant), Promosi Penjualan, Periklanan

b. Dependent Variabel: Pembelian Tidak Terencana

Sumber: diolah SPSS 18

Hasil uji $\mathrm{F}$ menunjukkan nilai F-hitung sebesar 14,765 dan nilai probabilitas sebear 0,000 dengan nilai df1 dan df2 masing-masing sebesar 2 dan 97. Nilai F-tabel pada tabel distribusi $\mathrm{F}$ dengan $\alpha$ : 0,05,df1:2, dan df2: 97 adalah sebesar 3,09 karena nilai F-hitung lebih besar dari F-tabel atau 14,300 >
3,09 maka, keputusan yang diambil adalah menolak Ho dan menerima Ha yaitu variabel X1 dan X2 secara simultan atau bersama berhubungan signifikan terhadap variabel Y. hal ini berarti variabel periklanan dan promosi penjualan secara bersama-sama memiliki hubungan yang signifikan terhadap perilaku 
pembelian tidak terencana studi kasus pada Mahasiswa dan Dosen Universitas Muhammadiyah Mataram

\section{G. Kofisien Determinasi (Adjusted $R$ Square)}

Koefisien determinasi menunjukkan besarnya kemampuan variasi nilai variabel independen dalam menjelaskan variasi nilai tabel dependen yang dinyatakan dalam presentase. Koefisien determinasi pada regresi linier berganda diindikasi dengan nilai Adjusted R Square.

Tabel 11.

Koefisien Determinasi

Model Summary

\begin{tabular}{|c|c|c|c|c|}
\hline Model & $\mathrm{R}$ & R Square & $\begin{array}{c}\text { Adjusted R } \\
\text { Square }\end{array}$ & $\begin{array}{c}\text { Std. Error of the } \\
\text { Estimate }\end{array}$ \\
\hline $\begin{array}{c}\text { di } 1 \\
\text { me } \\
\text { nsi } \\
\text { on } \\
\text { o }\end{array}$ & $.483^{\mathrm{a}}$ & .233 & .218 & 1.14329 \\
\hline
\end{tabular}

a. Predictors: (Constant), Promosi Penjualan, Periklanan

Tabel diatas menunjukkan nilai koefisien determinasi adalah sebanyak 0,218. Artinya bahwa variasi nilai pembelian tidak terencana mampu dijelaskan oleh variasi nilai periklanan dan promosi penjualan adalah sebesar 48,3\%. Sisanya sebesar 23,3\% nilai variabel pembelian tidak terencana dijelaskan oleh variabel-variabel yang tidak dimasukkan dalam penelitian ini.

\section{Pembahasan}

\section{A. Hasil Regresi Linier Berganda}

Berdasarkan persamaan regresi diatas dapat dilihat bahwa kedua koefisien variabel $\mathrm{X}$ yang bernilai signifikan yakni periklanan (X1) dan promosi penjualan (X2). Kekuatan hubungan tersebut dapat dilihat dari tingkat signifikasi yang lebih kecil dari tingkat alpha signifikasi 0,05 yang digunakan.

\section{B. Hasil Uji Hipotesis \\ 1) Uji F (Simultan)}

Berdasarkan hasil uji F (simultan) Promosi (periklanan dan promosi penjualan) pada tingkat kepercayaan 95\% $(\alpha=0,05)$ diperoleh hasil F-hitung 14,765 yang dimana hasil tersebut lebih besar dari Ftabel sebesar 3,09 atau 14,765 > 3,09. Yang berarti variabel periklanan dan promosi penjualan berhubungan signifikan secara simultan terhadap variabel pembelian tidak terencana (Y).dengan demikian dapat disimpulkan bahwa variabel periklanan dan promosi penjualan berhubungan signifikan secara simultan terhadap pembelian tidak terencana studi kasus pada Mahasiswa dan Dosen Universitas Muhammadiyah Mataram.

\section{2) Uji T (Parsial)}

Berdasarkan uji t (parsial) terhadap variabel periklanan dan promosi penjualan maka diperoleh hasil : kedua variabel $\mathrm{X}$ yakni periklanan dan promosi penjuaan memiliki hubungan secara parsial yang diperoleh atau dilihat dari t-hitung lebih besar dari ttabel yakni variabel periklanan sebesar 2,857 > 1,66o yang berarti periklanan secara parsial berhubungan dengan perilaku pembelian tidak terencana. Sementara itu variabel promosi penjualan juga memiliki t-hitung lbih besar dari t-tabel yakni sebesar $3,697>1,660$ yang berarti promosi penjualan memiliki hubungan secara parsial terhadap perilaku pembelian tidak terencana.

\section{3) Koefisien Determinasi}

Besarnya hubungan periklanan dan promosi penjualan menggunakan internet terhadap perilaku pembelian tidak terencana studi kasus pada Mahasiswa Dan Dosen Universitas Muhammadiyah Mataram dapat dilihat pada nilai koefisien determinasi (Adjusted $R$ Square) yaitu sebanyak o,218. Artinya bahwa variasi nilai pembelian tidak terencana mampu dijelaskan oleh variasi nilai periklanan dan promosi penjualan adalah sebesar $48,3 \%$. Sisanya sebesar $23,3 \%$ nilai variabel pembelian tidak terencana dijelaskan oleh variabelvariabel yang tidak dimasukkan dalam penelitian ini

\section{KESIMPULAN DAN SARAN}

\section{A. Kesimpulan}

Berdasarkan hasil analisa data dan pembahasan tentang "Hubungan Promosi Menggunakan Internet Terhadap Perilaku Pembelian Tidak Terencana Studi Kasus Pada Mahasiswa Dan Dosen Universitas Muhammadiyah Mataram” maka 
dapat ditarik kesimpulan yang diperoleh dalam penelitian ini adalah:

1. Ada hubungan yang positif dan signifikan antara periklanan menggunakan internet terhadap perilaku pembelian tidak terencana pada Mahasiswa Dan Dosen Di Universitas Muhammadiyah Mataram. Hal ini dibuktikan dengan t-hitung $(2,857)$ lebih besar dari t-tabel dengan taraf siginfikasi $5 \%$ dan $\mathrm{N}=98(1,660)$

2. Ada hubungan yang positif dan signifikan antara promosi penjualan menggunakan internet terhadap perilaku pembelian tidak terencana pada Mahasiswa Dan Dosen Di Universitas Muhammadiyah Mataram. Hal ini dibuktikan dengan nilai t-hitung $(3,697)$ lebih besar dari ttabel dengan taraf signifikasi $5 \%$ dan $\mathrm{N}=98$ $(1,660)$

3. Ada hubungan yang positif dan signifikan secaa simultan antara periklanan dan promosi penjualan menggunakan internet terhadap perilaku pembelian tidak terencana pada Mahasiswa Dan Dosen Universitas Muhammadiyah Mataram. Hal ini dibuktikan dengan nilai F-hitung $(14,765)$ lebih besar dari Ftabel dengan taraf signifikasi $5 \%$ dan $\mathrm{N}=97$ $(3,09)$

\section{B. Saran}

1. Agar mendapatkan hasil yang memiliki tingkat generalisasi yang lebih tinggi dan hasil penelitian yang lebih akurat lagi, sebaiknya penelitian selanjutnya mengambil tempat atau obyek penelitian di tempat lain dengan ukuran sampel yang lebih besar, sehingga hasil dalam penelitian ini lebih berlaku umum dibanding penelitian ini.

2. Hasil dalam penelitian ini bisa dapat dijadikan refrensi untuk penelitian lebih lanjut tentang Hubungan promosi terhadap perilaku pembelian tidak terencana, dan diharapkan dalam penelitian selanjutnya untuk menambah varabel yang diteliti, seperti semua variabel yang ada dalam promotion mix diantaranya advertishing, personal selling, direct marketing, public relation dan promosi penjualan.

3. Untuk menghindari pemberian jawaban oleh responden secara subjektif maka perlu dalam penelitian dilakukan teknik wawancara untuk memberika konsistensi dalam jawaban yang diisi oleh responden.

\section{DAFTAR PUSTAKA}

Arikunto, Suharsimi. 2009. Manajmen Peneltian. Jakarta : PT RINEKA CIPTA
Asosiasi Penyedia Jasa Internet. 2015. Indonesia Internet User. http://APJII.Or.Id. Diakses Pada 2 Februari 2018

Asosiasi Penyedia Jasa Internet. 2016. Perilaku Pengguna Internet Indonesia. http://APJII.Or.Id. Diakses Pada 2 Februari 2018

Dharmesta, B, S,. Dan T. H. Handoko. 2008. Manajmen Pemasaran : Analisis Perilaku Konsumen. Edisi Pertama Cetakan Keempat. Yogyakarta: BPFE

Engel, James F and Roger D Blackwell. Perilaku konsumen edisi ke 6 jilid kedua. Jakarta: Binarupa Aksara

Fitri, Irna. 2016. "Analisis Promosi Penjualan Online, Harga, Kepercayaan, Dan Kemudahan Terhadap Keputusan Pembelian Online Ceker Brontak (Studi Kasus Pada Ceker Brontak Bandar Lampung)". http:/digilib.unila.ac.id. Skripsi. Diakses pada 17 Februari 2018

Ghozali, Imam. 2011. Aplikasi Analisis Multivariat dengan program IBM SPSS 19 (edisi kelima). Semarang: Universitas Diponegoro

Ismu Fadli Haris. 2011. "Studi Mengenai Impulse Buying Dalam Penjualan Online Studi Kasus Di Lingkungan Universitas Diponegoro”. Skripsi. http://eprints.undip.ac.id. Skripsi. Diakses pada 17 Februari 2018

J Staton William, Michael J Etzel and Bruce J Walker. 2004. Foundation of Marketing. Tenth Edition. New York : Mc hill

J Staton, Wiliam. 1993. Strategi Pemasaran. Alih Bahasa oleh Dan Fruteki Fandi Ciptono. Jakarta: Penerbit Gramedia

Kotler, Philip \& Kevin L. Keller. 2012. Manajmen Pemasaran, Edisi 13. Penerbit Erlangga. New Jersey : Prentice Hall

Kotler, Philip and Gary Amstrong. 2008. Prinsip-prinsip Pemasaran. Edisi 12 Jilid 1 . Jakarta: Erlangga.

Loudon, D.L, dan Della Bitta, A.J. 1993. Consumer Behavior: Concept and Application. Singapore: Mc, Grow-Hill, Inc.

Lutfhiana, Revalina 2014 “Analisis Kualitas Pelayanan, Promosi Dan Hedonic Shopping Motives Yang Mempengaruhi Impulse Buying Dalam Pembelian Secara Online (Studi Kasus Pada Mahasiswi Universitas Diponegoro Semarang)”. Jurnal. Vol 5. No 2. http://eprints.undip.ac.id.. Diakses pada 17 Februari 2018.

Mcleod, Rymond, Jr. 2008 Sisitem Informasi Manajmen Jilid I Dan II, Terjemahan Oleh Ali Akbar Yulianto dan Afire R. Fitrianti, Jakarta: Salemba Empat

Mudrajab, Kuncoro. 2011. Metode Kuantitatif, Teori Dan Aplikasi Untuk Bisnis \& Ekonomi, Edisi Keempat. Yogyakarta : Sekolah Tinggi Ilmu Manajmen Ykpn.

Nurmanto, A Prasetyo. 2015. "Pengaruh Kemudahan Penggunaan, Kenikmatan Berbelanja, Pengalaman Berbelanja dan Kepercayaan Konsumen disitus Jual Beli Online Bukalapak.Com".

http://administrasibisnis.studentjournal.ab.ac.id. Skripsi. Diakses pada 17 Februari 2018

Purwanto. 2010. Model Perilaku Konsumen E-Commerce. Jakarta: Penerbit Gramedia

Ratih, Huriyanti. 2008. Strategi Pemasaran Paparan Marketing Mix. Bandung : Universitas Pendidikan Indonesia

Samuel, Hatane. 2013. "Pengaruh Stimulus, Media Iklan, Uang Saku dan Gender Terhadap Kecendrungan Perilkau Pembelian Impulsif Studi Kasus Produk Pariwisata”. Jurnal. Vol.2, No.1 http://puslit2.petra.ac.id/ejournal.. Diakses pada 17 Februari 2018.

Singgih, Santoso. 2008. Perilaku Konsumen. Jakarta: Universitas Guadarma 
Siregar, Sofyan. 2015. Statistika Terapan Untuk Perguruan Tinggi. Jakarta : Penertbit Kencana.

Sukestiyarno. 2014. Statistika Dasar. Yogyakarta : Penerbit ANDI.

Suryanto, M. 2007. Strategi Pemasaran. Jakarta: Balai Pustaka

Wells, Burnett dan Manarty. 2008. Promostion Mix. Jakarta : Repository Widyatama

WJS, Purwadaminta, 2008. Kamus Umum Bahasa Indonesia. Jakarta : Balai pustaka

Yusuf, H. Arif. 2015. Pemahaman Strategi Bisnis \& Kewirausahaan. Jakarta : Prenadamedia Group. 